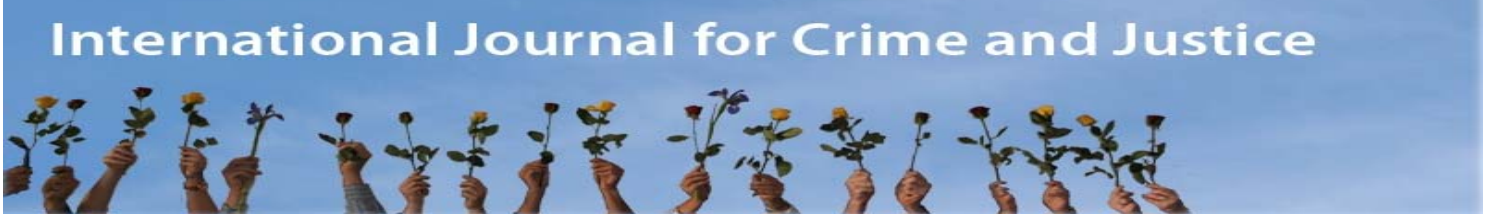

\title{
Policing Visible Sexual/Gender Diversity as a Program of Governance
}

\author{
Angela Dwyer \\ Queensland University of Technology, Brisbane
}

\begin{abstract}
Using interview data on LGBT young people's policing experiences, I argue policing and security works as a program of government (Dean 1999; Foucault 1991; Rose 1999) that constrains the visibilities of diverse sexuality and gender in public spaces. While young people narrated police actions as discriminatory, the interactions were complex and multi-faceted with police and security working to subtly constrain the public visibilities of 'queerness'. Same sex affection, for instance, was visibly yet unverifiably (Mason 2002) regulated by police as a method of governing the boundaries of proper gender and sexuality in public. The paper concludes by noting how the visibility of police interactions with LGBT young people demonstrates to the public that public spaces are, and should remain, heterosexual spaces.
\end{abstract}

\section{Keywords}

LGBT (lesbian gay bisexual transgender), sexualities, gender diversity, public spaces, bodies, heteronormativity, discipline

\section{Introduction}

Their mannerisms just like push the boundaries. It's not like, 'Yeah I'm gay, so what?' It's like, 'Yeah I'm gay, I'm in your face, now take it'. So usually it's something like that. (Misch, bisexual male, 19)

While Misch refers here to something that may generally be undetectable, this paper demonstrates how the subtleties of heteronormative gender and sexuality matter in public spaces with police. I argue that the boundaries Misch refers to are regulated by police as a program of governance about what it means to 'do' gender and sexuality 'properly' in public spaces. To explore this, I examined transcripts of interviews about lesbian, gay, bisexual and transgender (LGBT) ${ }^{1}$ young people's experience of policing in Brisbane, Queensland, Australia. The uneasy relationship between young people and police more generally is well documented in the literature (Cunneen and White 2011; Hinds 2007; McAra and McVie 2005) and this is reflected in the interview data generated in this study. Young participants perceived some interactions with police and security to be discriminatory. However, these data tell us nothing about the intentions of police and security personnel. In fact, the data could not be neatly categorised as either discriminatory or supporting and I suggest the actions of police and security personnel may have served another more subtle purpose in public spaces. 
In line with Mason (2002: 20), I argue police actions may serve to correct LGBT young people's behaviour on a broader scale as a '[v]isible yet unverifiable means of correction'. Conceptualising their interactions in this way enables an understanding of how the general public comes to interpret the appropriateness (or lack thereof) of displays of same sex intimacy in public spaces (Mason 2001). This in turn may subconsciously correct the public embodiment of queerness among LGBT young people by subtly encouraging them to regulate their own behaviour in line with these expectations. I argue this is how police interactions with LGBT young people may work as a program of governance (Dean 1999; Foucault 1991; Rose 1999) that regulates non-heteronormative bodies in public spaces. Police actions seem to be informed by notions of how LGBT young people represent non-heteronormative bodies out of place and how, subsequently, police may be seen to be 'punishing or constraining the public visibility' (Tomsen 2009: 39) of these young people. To discuss these issues, I draw from the work of Mason (2001, 2002), Moran and Skeggs (2004), Tomsen (2009), Dalton (2007), and Valentine (1993) to elaborate how the bodies of LGBT young people are constructed as out of place in heterosexual public space. As Mason (2001: 25) achieves in her examination of violence experienced by lesbian women, I want to position the actions of police officers in relation to these bodies out of place 'in the wider context of discursive statements of sexual visibility'.

This framework was applied to examine qualitative data from 35 interviews conducted with LGBT young people mostly at a LGBT youth support service in Brisbane during drop-in times (12.30pm to $4.30 \mathrm{pm}$, four days per week, from approximately October 2008 to April 2009). Participants were asked questions about their knowledge and perceptions of police, and their specific interactions with police in public spaces. By applying this alternative framework to police-LGBT youth interactions, this paper departs from explanations grounded in notions of causation, individuation, and blame-seeking (see for instance, Crime and Misconduct Commission 2009) to think differently about these interactions. Rather, the paper is concerned with how LGBT young people's accounts of policing and security checking speak to the terrain in which particular versions of being in public space are sanctioned in specific contexts. The key interest is, then, how these 'enable such situations to even begin to say something about the object' (Mason 2001: 32); in this instance, policing and security checks.

\section{Poststructural framework: A focus on visible non-heteronormative bodies}

The research discussed in this paper was underpinned by poststructural assumptions about the concepts of the body (Foucault 1984; Kirby 1997), discipline (Foucault 1977), visibility (Skeggs 1999), heteronormativity (Jackson 2003), place (Dalton 2007; Moran and Skeggs 2004), and performativity (Austin 1979). Bodies are inscribed (Foucault 1984) by discourses of queerness that mark the body as a text of discursive knowledge informing 'the very matter of [the] body's material constitution' (Kirby 1997: 3). This paper argues the bodies of LGBT young people enact non-heteronormativity (Jackson 2003) in ways that may be read as discursive texts by police. This enables an understanding of how the body can be 'done' (Butler 1990) in ways that perform a discourse of non-heteronormative queerness (Jackson 2003) and that may be read as discursive texts by police and security. This includes language which functions in a distinctly performative manner (Austin 1975), with talk understood as 'performing an action' by way of 'speech acts' that literally perform the act of which they speak. Police and security appear to read and 'detect' bodily conduct that demonstrates what the young people called 'queerness'.

Reading bodies in this way implies a certain visibility and poses questions about 'what should be visible and what should not, who should occupy space and who should not' (Moran and Skeggs 2004: 7). This points to how 'we can "see" same-sex sexualities' (Mason 2001: 24), with LGBT young people arguably seen as 'the subject-to-be-looked-at' (Young 1996: 210). They are spectacular examples of how not to do heterosexuality, 'something which can be pointed to and seen' (Angel 1994: 62) in public spaces. Most importantly, visibility is about place - 'recognition of being in and out of place that invariably invokes regimes of placement' (Moran and Skeggs 
2004: 7). LGBT young people represent bodies out of place: both in terms of not being heterosexual and of being seen in public places, they represent 'ungovernable' (Dalton 2007: 385) bodies in need of regulation. They have breached the boundary of proper heterosexual behaviours, a boundary that 'divides, separates and distributes ... [and] that has clarity, is impermeable, stable and fixed' (Moran and Skeggs 2004: 10). In this study, police and security surveillance of this boundary is explored.

In surveilling the boundaries of what it means to do sexuality and gender properly in public spaces, this paper draws on Foucault (1991), Dean (1999), and Rose (1999) to analyse police and security interactions with LGBT young people as a program of government. '[G]overnment entails any attempt to shape with some degree of deliberation aspects of our behaviour according to particular sets of norms and for a variety of ends' (Dean 1999: 10). This project works on two levels. In the first instance, it is a regulatory project which works on and with the bodies of people, bodies which in some way have been defined as ill-disciplined and therefore in need of regulation (Dean 1999). Police actions seek to correct and rediscipline these deviant bodies by redirecting their conduct in public spaces. Alongside this regulatory regime runs a project of self-government. This involves 'self-inspection' which enables a person 'to act upon our bodies, souls, thoughts, and conduct in order to achieve' (Rose 1999: 11) a particular outcome. LGBT young people may work on reshaping how they govern themselves and their conduct so they 'pass' better or 'fit in' better to heterosexual spaces when their bodies fall outside the heteronormative expectations required in public spaces.

Such a process is not exclusive of LGBT young people and police and security personnel may involve themselves in these processes too. However, in this study, these forms of government were chiefly defined by notions of placement, where a person feels out of place in heterosexual public spaces because they are gay or lesbian or transgender. As Valentine (1993: 406) notes, persons with diverse sexuality and/or gender 'feel out of place because of the orientation of these places towards heterosexual couples'. Those who do not conform to the heterosexually gendered codes of dress and behaviour expected in public spaces are subject to the governmental project (Dean 1999; Foucault 1991; Rose 1999) to make their conduct align better with these heteronormative expectations. This framework not only facilitates further thinking about the impact of interactions between LGBT young people and police and security personnel on the active participants but also the impact on those witnessing the interactions in public spaces.

\section{Constraining the public visibilities of bodies out of place}

Police and security personnel appear to constrain public visibility of LGBT young people as bodies out of place in public spaces on the basis that their bodies fail to align with heterosexual and gendered normality. 'Constrain' is used here with reference to Foucault's (1977: 11) elaboration of constraint as a discipline: 'a system of constraints and privations, obligations and prohibitions'. Constraint was subtle and was grounded in the sense of being out of place (Moran and Skeggs 2004; Valentine 1993) with comments focusing on feelings, weird looks - almost undetectable limitations and moderations of their behaviour. Physical constraint was less common. In other words, forms of constraint were attached to how their bodies made their gender or sexuality visible in ways that transgressed heteronormative expectations: if I'm not looking really gay they'll be a lot nicer' (Nikolas, gay male, 18).

\section{'I look like a chick and they just call me a slut'2: Constraining gender diversity in public spaces}

Police and security actions appeared to constrain gender diversity in a range of subtle ways but were nonetheless perceived by LGBT young people as telling them they were doing gender (Butler 1990) in ways that were out of place in heteronormative public spaces. Alex (male to female transgender, 25) suggested being out of place in terms of gender diversity was 'a power thing; you're giving up your right being male and dominant'. According to many of our 
participants, police officers detected their gender diversity and sometimes moved out of the spaces they inhabited to avoid them:

When I was in drag yes ... it trips them out ... they just wanted to get away from me. (Alexis, gay male, 19)

One of my friends ... who is a transgender person and she still, she's still male but she wears a wig and dresses up and everything and the cops ripped her wig off in public once to taunt her. (John, gay male, 18)

In both these cases, it seems that the ways in which these LGBT young bodies queered heteronormative expectations of gender was detected by police and acted upon. Although far removed from targeted abuse of LGBT people in history (Tomsen 2009), police actions nonetheless made it clear to LGBT young people that their physical presence was not appreciated in heterosexual public places and they were out of place. Police appear to have decided these young people were a problem and subsequently sought to constrain, albeit subtly, their gender diversity. This could be problematic for LGBT young people where police have expectations about how young people behave and it is at odds with their embodiment of gender. One interviewee, Tayden, discussed this in relation to her experience with security officers who worked in a youth detention centre where she was detained at a younger age:

I'm a pretty butch girl so I've never had any really good relationships with police ... I didn't really get treated that well cause they were like, 'Ah you should stand up for yourself you're butch ha ha', and it was just like 'Yeah I'm a 14 year old kid with a shaved head'. (Tayden, pansexual female, 19)

Visibility and surveillance are central to how subtle assumptions like these act as forms of constraint. This makes known to LGBT young people that gender diversity situates them as out of place (Moran and Skeggs 2004). How this gender diversity is perceived by police seems to inform how LGBT youth-police interactions unfold:

You know someone's out of line. There was one, I don't know I think he was transfemale or gender queer of some sort, but he was just you know he seemed different to some of the guys who were on the train. They were saying stuff and you know he sort of just retaliated because he didn't like it. There was police on the train at the time and they've told him to settle down. (Freddy, female to male transgender, 25)

Even though the transperson was being harassed by people on the train, Freddy notes how police admonished the person who retaliated rather than the people harassing the transperson. This type of interaction sent a clear message to Freddy that a gender diverse person, but not others, deserved to be at least reprimanded by police in public spaces and made him wonder if those who were gender diverse could anticipate assistance from police in times of distress. This is a key outcome of these forms of interactions. Not only does Freddy become aware of this but police actions in this case may constitute a demonstrative spectacle (Angel 1994) of how some police officers consider it is acceptable to harass the gender diverse in public spaces.

'Public affection ... It's not allowed in Queen Street'3: Constraining sexualities in public spaces

According to LGBT young people, same sex intimacy was constrained consistently by police and security personnel. Alex noted this could be as subtle as a look from police: 
I don't know it's just very different. I've been with my boyfriend with police around but just because we're pretty normal looking people. They kinda just give you a weird look and look the other way. (Alex, male to female transgender, 25)

These 'weird' looks act as a form of constraint, enough to make it clear to this young person they were considered out of place and to invoke self-governance measures to not appear so outwardly 'gay'.

Young people's accounts in this study also demonstrated more overt examples of nonheteronormative behaviour being constrained by police and security. These forms of constraint ranged from avoiding contact to physically separating and reprimanding LGBT young people for being intimate with their same sex partners. Specifically, holding hands, kissing, or hugging between same sex couples visibly drew the attention of police as out of place in public space. Some young people acknowledged police may react to how LGBT young people are 'out and proud' and can flaunt this (Mason 2002) in ways that attract police attention:

Some of the younger dykes out there that are like 15, 16. They're still at that younger stage where they find it necessary to write the word lesbian on everything they own and shit like that ... some of them cop it a fair bit. I think there's a bit of a street mentality where people are like, 'Well we don't run around writing heterosexual on all of our stuff. Why do you have to wave it in our face?'. (Ticket, lesbian female, 19)

A lot of young LGBT people are scared of police as well because I guess with our culture, it's not socially acceptable to do a lot of things out in public like kissing, hugging, and I think especially a lot of young ones just like to push their buttons. (Tayden, pansexual female, 19)

Even if this is how these young people are perceived, they continue to have the right to congregate in public spaces and recreate with other young people. Interestingly, these views align with those expressed about the Sydney Gay and Lesbian Mardi Gras (Waitt and Stapel 2011: 208) where interviewees noted how they thought visible displays of 'raunchy' intimacy should not be made public by the Mardi Gras event organisers. Displays of raunchy same sex desire are considered by some to be unruly (Dalton 2007) and clearly out of place, a view that Ticket suggested the police share. Police are situated here as regulating the boundary (Moran and Skegg 2004) of 'waving it in your face', with individual officers imbued with the discretionary power to decide who has and has not transgressed this boundary.

Sometimes these forms of regulation happened in the absence of visible same sex affection and were directed more towards the proximity of bodies that were visibly queer in public spaces. This was discussed by Nikolas in relation to security officers in a train station and Ticket in relation to police officers in public spaces:

We were just sitting like we were sitting in the Metro Valley train station and I was like with a bunch of my gay mates we were just coming home from the Beat. I think it wasn't even that late and we weren't even drunk and the security just came up grabbed my friend ripped him out of the chair and kicked us out. He was like, 'You're not allowed to sit down', and he was like, 'I've sat here before and no one's said anything', and he's like, 'Don't, you're not allowed to sit here' and he threw us out of the train station. (Nikolas, gay male, 18)

Jimmy and I will get pulled up if its 5:30 in the morning and we're staggering around the Valley in like fats and candy and I've got my studded jacket and my 
Mohawk up. They'll ask for ID and they'll see the addresses and they're like, 'Do you two live together?' and we're like 'Yeah' and they're like 'Ah are you together, like gay?'. (Ticket, lesbian female, 19)

For Ticket, it was clear police have detected that her and Jimmy were in a lesbian relationship and she speculates about whether or not this is the police motivation for pulling them up. While it is not precisely clear what motivated the security personnel to physically intervene in the behaviour of Nikolas's friends, Nikolas believed their actions may have been informed by how security personnel 'read' their bodies as queer and therefore out of place (Moran and Skeggs 2004 ) in a public space like a train station. As gay young males, their bodies signified matter out of place - the materiality of their queer bodies had no place in this heterosexual public space.

At times, rather than having their conduct explicitly acted upon by police and security, some LGBT young people noted how inaction by those with authority appeared inappropriate to the situation. For example, Quintin notes how 'whenever a situation has arisen between a group of young people who have been gay and a group that have been straight, generally I don't feel like we've been given time' (Quintin, gay male, 17). Quintin recounts a situation where no action by police and security seemed to have had a similar effect to the situation recounted above by Nikolas in that it tells the LGBT young people involved that they are the ones out of place in heterosexual public space:

We were bashed on a train for being gay by a really large group of young people probably 20 plus and like not that many of us, there's not a lot we could do about it. Anyways we managed to get off the train and we phoned the police and they came and the ambulance officers came and we're trying to tell the cops that our friend is still down there being physically attacked and they basically ignored what we were trying ... They're just like 'Calm down' and it was just really painful and eventually it was the ambulance officers that went down on to the platform themselves before the police actually even bothered to go down there. When they did go down, the train was allowed to leave with all the people still on it, witnesses, the people who had actually committed the crimes had either fled from the train station or got back on the train and left so nothing proper was done about it. (Quintin, gay male, 17)

Quintin believed that police inaction in this instance was evidence of police detecting queerness in him and his mates and the inaction was a way of constraining this queerness in public spaces. Police inaction in this example may be interpreted as a form of governmental regulation that demonstrates to LGBT young people that those embodying queerness are not deserving of police assistance. Furthermore, the spectacle (Angel 1994) of situations like the one Quintin recounted on the train may visibly demonstrate to onlookers how these young people do not deserve police assistance.

Language used by police and security personnel could also be described as a mechanism used to constrain the actions of LGBT young people. In this study, homophobic pejoratives were not often recorded yet when they were used by police in particular, the young person recognised the words were spoken as an act of constraint. When asked if police had ever used this language in interactions with LGBT young people, Xavier (female to male transgender, 22) stated, 'Oh yeah, "You fucking faggot, I'll fuck you like a bitch that you are"'. Other young participants noted how these forms of language served to constrain not only the behaviours of those on the receiving end of the comments, but also those who witnessed these exchanges:

One of my friends was pulled over once and he's the biggest queen you'll ever meet ... he's got the pitched voice, he's walks, sounds, talks like a stereotypical gay 
guy and he was pulled over. I was in the car at the time, the police had pulled him over just for a routine breath check, doing their job. He was breathalysed. He said 'Is everything alright officer?' and he said 'Oh shut up you stupid faggot' ... I said nothing because they're the police and I don't want to get into trouble. I've been in trouble, don't want to more. (Pinky, gay male, 18)

Pinky knew the situation referred to here was unfair and felt he should say something yet he did not. Homophobic language had its desired effect: it acted (Austin 1975) upon Pinky in ways that lead him to constrain his behaviour for fear of potential further trouble from police. This, in turn, represents the material effects of homophobic language for LGBT young people. Pinky implements a new way of self-management in public spaces (Rose 1999). When Pinky reflected on the situation, he realised he will always expect to be the subject of homophobic language from police and the public:

You're going to get that from everyone if you hold hands, if you kiss in public, just put your arm around their shoulder, you're going to get looks, you're going to get whispers you're going to get people calling out 'Faggots' or 'Dykes'. (Pinky, gay male, 18)

Pinky recognised that doing same sex intimacy in public spaces in any form made nonheteronormative sexualities visible (Skeggs 1999) in ways that situate them as out of place (Moran and Skeggs 2004; Valentine 1993). More importantly, it is clear that one-off remarks like these align with what Mason (2002: 20) calls a '[v]isible yet unverifiable means of correction' - they correct same sex intimate behaviours in public spaces by telling them they are not welcome in these spaces. They are pushed out ever so subtly and language works as an action which seeks to privatise same-sex intimacies (Berlant and Warner 1998).

LGBT young people noted police actions similarly worked as a means of correcting same sex intimacy in public spaces.

They're always pulling up if a guy lays on another guy or if a girl lays on another girl, they're pulling it up pretty fast but like if I laid on a guy, they wouldn't overly worry about it too quickly. (Sarah, male to female transgender, 17)

While Sarah is technically out of place as a male to female transgender young person, she identifies as a female with a boyfriend and they 'pass' successfully as heterosexual - and in place in heterosexual public space. This interaction highlights that, while the imperative to hide diverse sexuality has fallen away somewhat in contemporary times, the common expectation to do this 'continues to serve as the favoured benchmark against which all representations of homosexuality are measured' (Mason 2001: 24). Police appear to use this benchmark to 'measure' behaviours of LGBT young people in public spaces. It is assumed they will adhere to unspoken expectations about not 'flaunting' their sexuality in public spaces, and properly adhere to homonormative ideals (Bell and Binnie 2004); that is 'non-threatening, almost invisible' queerness (Waitt and Stapel 2011: 209).

\section{Punishing the public visibilities of bodies out of place}

Homophobic language and legislative frameworks were also used by police and security personnel to punish public visibilities of this group as a form of authorised government of nonheteronormative bodies. This means they used the powers they had as police and security personnel to formally punish the LGBT young people for embodying or enacting queerness in public spaces. While punishment was less common than actions that sought to constrain, police and security interactions with LGBT young people could shift towards punishment in two ways: through homophobic language and through applying legal sanctions. 
'Once you wear the uniform, leave the other shit at home': Language as punishment

According to LGBT young people's accounts, police used language to punish those considered out of place due to visible non-heteronormativity. This was particularly the case for transgender young people. For example, one participant recounted a situation where a police officer physically acted on the body of a young transgender female: 'One of my friends Holly who is a transgender person ... she's still male but she wears a wig and dresses up and the cops ripped her wig off in public once to taunt her' (John, gay male, 18). This situation clearly exemplifies police acting on a young gender diverse person, the only case encountered in this study. More common was the use of language to punish transgender bodies for being out of place in public space:

One person ... she's transgender, in the process of becoming a woman, was asked to show her ID, and it came up male ... and they were saying 'But you're a fucking male ... stop lying to us'. It was pretty obvious she looks like a girl. (Pinky, gay male, 18)

These words appear no less effective than physical actions in that they produce similar results: they admonish transgender visibility in public spaces as 'soft targets ... disciplined for their gender non-conformity' (Tomsen 2009: 42). Police actions demonstrated to Pinky, to the transgender young male involved and to onlookers that these bodies are out of place and in breach of legislative frameworks. They are the subject-to-be-looked-at (Young 1996), seen to be defying heteronormative boundaries, and are ill-disciplined in this defiance. Homophobic language was also used to punish LGBT young people for displaying gender and sexuality in a way that transgressed the expectations of heteronormativity in public spaces:

When I was with my friends that look really gay and the police actually said something really rude to him ... I really don't want to say ... so it's like if you look gay it's like you're asking for it that's pretty much how it comes across. (Misch, bisexual male, 19)

They just drove past saying 'Queer faggot!' and I'm like 'Whoa!'. So I went off at them then I got charged verbal abuse ... I was like fucking - excuse my language I was like, 'What the fuck, what! It's against the law to be gay these days?' A hundred and fifty dollars like I'm not paying for this. I took the fine and ripped it up. (Alexis, gay male, 19)

About me going to beats getting caught and all that, I was being hassled a bit like, 'Don't touch his hands he'd be filthy, he'd be diseased'. (Pinky, gay male, 18)

Pinky was punished for seeking out sex with another male in a 'beat'4 and police did this by drawing on discourses of HIV transmission that have stigmatised gay men in the past. Misch's friend was punished for looking 'really gay' and Alexis was punished for responding to language from police that he knew was inappropriate. These three examples may be thought of as performative (Austin 1975): these words perform how LGBT young people who visibly embody queerness are dirty, deviant, unclean, and out of place. Police homophobic language quite literally performs the actions of which they speak - it acts as a discursive practice that shapes the actions of the young person to certain ends. Reflecting on the work of Dalton (2007: 398), these language processes may act as a practice that 'marks them as deviant and enshrines this quality in archives where gay men are named as criminal subjects'. While Dalton refers here to the historical archives of police 'stings' with men in public beats, these qualities may be enshrined in police case notes as a contemporary archive. 
'I see you live with a bunch of lesbians': Police use of legislative punishment

Police and security personnel also punished public visibilities of this group via authorised legislative forms of punishment. These actions included issuing fines for kissing a same sex partner to physically intervening on same sex couples in public spaces. Although these actions are clearly unfair that police issue fines for this conduct, it can fall within the boundaries of the legislation under which these decisions are made. Individual officers have in these cases interpreted the legislation broadly (in terms of public offence) and issue fines as punishment for visibilising their non-heteronormative intimacies in public spaces.

Even though there were times when young participants were unsure if it was their sexuality that police responded to, elements of situations recounted in interviews suggested this may be an issue. Indeed, at least one LGBT young person concluded police actions were based on displays of same sex intimacy in public places:

I was walking through Queen Street with one of my friends and we were coming from Fat Louis'. We'd had a few drinks. We weren't drunk going over to the train station ... We were holding hands through Queen Street and the police pulled us over and like 'You've been drinking haven't you? Where have you been drinking?' and I'm like 'Fat Louis" and they're like 'Oh don't lie to us', took us back to the cop shop and gave us each a $\$ 100$ fine ... drinking in public. (Nikolas, gay male, 18)

I got a $\$ 125.00$ fine for telling a copper they looked hot in their uniform, this male cop. If I had of been some big breasted blonde bimbo, he probably would have let me off the fine ... but 'cause he was a straight male copper that was insulting to him ... 'cause I was in a car when I said it, and we were driving past him, the way he charged me was he said I had my body parts out the window ... so he wrote the fine out under that and they had me in the interview room and he told me that he was giving me the fine because that offended him ... 'cause he knew he couldn't give me a fine just for telling him he was hot. (Mac, gay male, 19)

It is not entirely clear if Nikolas and his friend are being punished by police for being queer in public spaces, but this is the message he received from this interaction. Mac, however, was sure the fine he was issued was motivated by his demonstration of same sex desire towards a male police officer. His behaviour breached the boundaries of heteronormative expectations in public space and he was formally punished for it. Police actions in these examples constrained not only the behaviours of those who police initially interacted with but their actions also defined acceptable levels of LGBT behaviours on a broader, more publicly visible scale. Onlooking LGBT people learn they need to regulate how they behave in public so as to avoid attracting similar police attention. Police actions discursively mark these bodies and same sex intimacies in public spaces as deviant, rendering them 'criminal subjects' (Dalton 2007: 398).

The use of punishment by police officers was not always so subtle or ambiguous in terms of enacting non-heteronormative sexualities and/or genders. Indeed, some examples demonstrated how legislative frameworks, which are 'never unambiguously and precisely written' (Chan et al. 2004: 73), afforded police opportunities to use discretionary powers in ways that would otherwise constitute a breach of basic human rights:

The cops, some of them can be better than others. But some are strict on kissing in public ... I've seen a couple of people actually ticketed for being in the street kissing, two guys. (No Name, bisexual male, 19)

The cops came up to them and started harassing them, pulling them apart and saying they were causing a nuisance to the public, and if they keep doing it 
they're going to handcuff them and take them away ... just for kissing in public. I got in trouble for public nuisance because I had no clothes on, that is understandable, but kissing in public, it's fucking ridiculous ... and I couldn't say anything cause I wasn't sober and underage ... and you get in trouble for interfering. (Jimmy Von D, lesbian female, 16)

Like Pinky, Jimmy Von D had come to know about how same sex intimacy can be out of place, and how it may be problematic to respond to this even if she knows it is unfair for police to regulate these activities. The men in the examples above constitute 'the existence of an unruly desire that is both out of place (by virtue of being public) and ungovernable' (Dalton 2007: 385). The police acted to regulate this unruly desire and, in turn, made visible to No Name and Jimmy Von D that displaying same sex intimacy in public places deserved punishment. Another gay male participant, Alexis (gay male, 19), was twice fined by police: first, for 'making out at a train station' with his male partner - 'The coppers came along and fined us actually ... this is public offence or some crap ... fined for public disturbance' - and, second, for 'making out' in a shopping centre with his male partner - 'at like 9 at night on a late night; I got charged again ... public nuisance or disturbance ... I'm like "This is not cool. Would you like me to go do it in a hole?"'. Alexis was well aware these police actions fell outside the boundaries of sanctioned police discretionary powers yet his only means of recourse was to not pay the fine: 'haven't paid it ... it was just making out with a guy that you like in public - Jesus Christ not guilty'. Alexis resisted the punishment police gave him, a move which would undoubtedly serve to criminalise him further.

These examples demonstrate the application of the Queensland Summary Offences Act 2005 (2011: s.5.6). This Act includes the offence of public nuisance ${ }^{5}$ and behaving in an offensive way' which police interpreted here as inclusive of same sex intimacy in public spaces. Particularly problematic in these examples was how, just as police officers 'assumed entitlement to gaze upon semi-naked bodies' of lesbians in Lamble's (2009: 120) work, so too did officers in this study assume entitlement to intervene in expressions of same sex intimacy in public spaces. Male-to-male intimacies are defined here as a nuisance and as offensive which is reminiscent of past times when anal sex was still criminalised (Comstock 1991; Wotherspoon 1991). Examples discussed by interviewees in this study seemed to work through the assumption that public space is a pure, moral space in which same sex affection constituted improper, unclean use of this space. That the public could be 'offended by it' and that it is 'disgusting' suggests police operate similar to Douglas's notions of abjection and space where dirt is associated with same sex affection, something Dalton (2007: 380) has noted in relation to historical policing of beat spaces where 'the logic of gay sexuality as diseased played out'. Either way, defining same sex affection in this way in public directly contravenes how these laws are intended to be used by police and security.

\section{'Under their breath': Concluding thoughts}

'Under their breath' was how Pearl (male to female transgender, 19) described the subtleties of constraint and punishment used by police and security and this captures succinctly the dynamics of how this happens with LGBT young people. The accounts presented, according to Hall (2005: 69), may be reminiscent of hate crime where this acts as 'a message crime' - it conveys a strong message to the general public about a particular person or group is 'different, unwelcome and that any member of that community could be the next victim'. However, we cannot just say that police use of homophobic language with these young people is a simple case of a hate crime incident for instance so how we think about this has to be different. While the data here may not resemble hate crime in that we know nothing of police intentions, it nonetheless produces material effects for LGBT young people who are subject to, or witnesses of, police actions. Police and security practices subtly constrain and govern young LGBT bodies in ways that blend into the fabric of public spaces, yet still highlight the importance of regulating 
bodies failing to align with heternormative genders and sexualities. The actions of police in public spaces send a message to the general public about the inappropriateness of same-sex intimacies in public spaces. The key issue warranting further consideration is how we have moved beyond this in a shifting contemporary landscape of subtle forms of hate crimes and incidents, and constraints and punishments.

Most importantly, revisiting the framework we use to read police interactions with LGBT young people enables us to think differently about it. While past research has been quick to condemn police actions, these rush-to-judge approaches may overlook the subtleties of power relationships that both constrain and enable. Furthermore, the framework generates a different way of thinking about the impact of these interactions. A poststructural framework shows how the public may come to know (Mason 2001) which bodies are regarded as being out of place through the actions of police, even if the outcomes of these interactions can be constraining and productive in varying contexts.

This also highlights the wider governance project that LGBT young people, and even police officers and security personnel, may engage in as a result of their interactions. Ultimately, according to Mason (2002: 21), 'when humans are rendered recognisable as certain types of individuals, we assume responsibility for modifying and constraining our behaviour, and our sense of self, so as to conform to normalised expectations and conventions'. LGBT young people may be considered as falling outside the expectations of heterosexual public spaces as they fail to conform to heterosexually gendered expectations of these spaces. There is little doubt that concealing diverse sexuality and gender, and ensuring they pass in public space, is 'the favoured benchmark' (Mason 2001: 24). This benchmark appears to be that which police are 'measuring' the public behaviours of LGBT young people in public spaces. It is generally assumed they will adhere to the unspoken expectation that they will not 'flaunt' their sexual preference in public spaces, that they will properly adhere to what Bell and Binnie (2004) call homonormative ideals; that is gentrified, respectable, benign queerness. While this may seem reasonable enough at first glance, this research suggests this may be a lofty ideal to attain in public spaces where young people may be considered a threat more generally (Carrington and Pereira 2009). This may make the self-management (Foucault 1991; Rose 1999) of conduct doubly difficult for LGBT young people given this may be required to ensure they have productive interactions with police and security.

It is surprising to note that, since the publication of Valentine's (1993) important article nearly 20 years ago, her conclusion still appears to hold weight in a contemporary setting: 'The evidence presented in this paper confirms that heterosexuality is the dominant sexuality in modern Western culture' (p. 410). The evidence discussed in the current paper highlights how people who transgress heteronormative expectations in public space will be subjected to some form of regulation by others. It may be argued this is part of a broader governmental project to maintain the heterosexually gendered nature of public spaces, with police working subtly and almost invisibly to 'banish raunchy counterpublic sexualities' (Waitt and Stapel 2011: 209). The diverse sexualities and genders embodied by LGBT young people in this study unsettled heteronormative public spaces because they embodied desires and genders which are out of place and in need of regulation (Dalton 2007; Skeggs 1999). Participant comments in this study highlight how some police and security personnel may be working through an imperative to keep same-sex intimacy in any form private and that heterosexual affections pass invisibly under the attention of police and security. This is suggestive of what Berlant and Warner (1998: 559) identify as 'the privatisation of sex and the sexualisation of private personhood'. Discourses of heterosexuality and heteronormativity make this possible, with the focus being on privatising same sex intimacy or at least normalising and correcting these behaviours in public spaces. 
This paper demonstrates a range of practices that seek to constrain and therefore govern the public visibilities of sexual/gender diversity in the conduct of LGBT young people. Security personnel and police actions serve as regulatory practices in a range of different ways: they regulate conduct they deem to be out of place in public spaces; they enrol LGBT young people in a project of self-management to minimise the contact they have with police and security; and they spectacularly demonstrate to onlookers the power of being visibly queer and therefore unwelcome in public spaces. All these points demand further consideration if we are to better understand the outcomes for those involved. In addition, it speaks to the need of further education and training for police officers and security personnel if LGBT young people are to be protected by these personnel in public spaces.

Correspondence: Angela Dwyer, School of Justice, Faculty of Law, Queensland University of Technology, Brisbane Qld 4001, Australia. Email: ae.dwyer@qut.edu.au.

1 In this project, LGBT was used to refer to sexualities and genders which fall outside the boundaries of heteronormative gender and sexuality. For instance, young participants not only identified as lesbian, gay, bisexual, and transgender, but also as undecided, same sex attracted, heterosexual trans, and pansexual.

2 Butch, gay male, 16

3 Sarah, male to female transgender, 17

4 'Beat' is an Australian slang term used to refer to the use of public toilets for anonymous sex with other men (Johnson 2008). These spaces are referred to as cottages in the United Kingdom (Johnson 2007).

5 A person commits a public nuisance offence if:

(a) the person behaves in a disorderly way; or an offensive way; or a threatening way; or a violent way; and (b) the person's behaviour interferes, or is likely to interfere, with the peaceful passage through, or enjoyment of, a public place by a member of the public.

\section{References}

Angel M (1994) Pedagogies of the obscene: The specular body and demonstration. In Matthews J (ed) Jane Gallop Seminar Papers. Canberra: The Australian National University: 61-71.

Austin JL (1975) How to do Things with Words. Oxford: Oxford University Press.

Bell D and Binnie J (2004) Authenticating queer space: Citizenship, urbanism and governance. Urban Studies 41(9): 1807-1820.

Berlant L and Warner M (1998) Sex in Public. Critical Inquiry 24(2): 547-566.

Butler J (1990) Gender Trouble: Feminism and the Subversion of Identity. New York: Routledge.

Carrington K and Pereira M (2009) Offending Youth: Sex, Crime and Justice. Sydney: Federation Press.

Chan J, Bargen J, Luke G and Clancey G (2004) Regulating police discretion: An assessment of the impact of the NSW Young Offenders Act 1997. Criminal Law Journal 28(2): 74-92.

Comstock GD (1991) Violence against Lesbians and Gay Men. New York: Columbia University Press.

Crime and Misconduct Commission (2009) Interactions between Police and Young People. Brisbane: Crime and Misconduct Commission.

Cunneen C and White R (2011) Juvenile Justice: Youth and Crime in Australia (4th edn). South Melbourne: Oxford University Press.

Dalton D (2007) Policing outlawed desire: 'Homocriminality' in beat spaces in Australia. Law Critique 18: 375-405.

Dean M (1999) Governmentality: Power and Rule in Modern Society. London: Sage.

Foucault M (1977) Discipline and Punish: The Birth of the Prison. London: Penguin.

Foucault M (1984) Nietzsche, genealogy, history. In Rabinow P (ed) The Foucault Reader. London: Penguin: 76-100.

Foucault M (1991) Governmentality. In Burchell G, Gordon C and Miller P (eds) The Foucault Effect: Studies in Governmentality. Chicago: University of Chicago Press: 87-104.

Hall N (2005) Hate Crime. Devon: Willan. 
Hinds L (2007) Building police-youth relationships: The importance of procedural justice. Youth Justice 7(3): 195-209.

Jackson S (2003) Sexuality, heterosexuality and gender hierarchy: Some reflections on recent debates. In Weeks J, Holland J and Waites M (eds) Sexualities and Society: A Reader. Cambridge: Polity: 69-83.

Johnson P (2007) Ordinary folk and cottaging: Law, morality, and public sex. Journal of Law and Society 34(4): 520-543.

Johnson P (2008) Offences against morality: Law and male homosexual public sex in Australia. Alternative Law Journal 33(3): 155-159.

Kirby V (1997) Telling Flesh: The Substance of the Corporeal. New York: Routledge.

Lamble S (2009) Unknowable bodies, unthinkable sexualities: Lesbian and transgender legal invisibility in the Toronto women's bathhouse raid. Social Legal Studies 18(1): 111-180.

Mason G (2001) Body maps: Envisaging homophobia, violence and safety. Social \& Legal Studies 10(1): 23-44.

Mason G (2002) The Spectacle of Violence: Homophobia, Gender and Knowledge. London: Routledge.

McAra L and McVie S (2005) The usual suspects? Street life, young people and the police. Criminology and Criminal Justice 5(1): 5-36.

Moran L and Skeggs B (2004) Sexuality and the Politics of Violence and Safety. London: Routledge.

Rose N (1999) Governing the Soul: The Shaping of the Private Self. London: Free Association Books.

Skeggs B (1999) Matter out of place: Visibility and sexualities in leisure spaces. Leisure Studies 18(3): 213-232.

Summary Offences Act 2005 (2011)Reprint No. 2C. Brisbane: Office of the Queensland Parliamentary Counsel. Available at http://www.legislation.qld.gov.au/LEGISLTN/CURRENT/S/SumOffA05.pdf (accessed 30 July 2011).

Tomsen S (2009) Violence, Prejudice and Sexuality. New York: Routledge.

Valentine G (1993) (Hetero)sexing space: Lesbian perceptions and experiences of everyday spaces. Environment and Planning D: Society and Space 11: 395-413.

Waitt G and Stapel C (2011) 'Fornicating on floats'? The cultural politics of the Sydney Mardi Gras parade beyond the Metropolis. Leisure Studies 30(2): 197-216.

Wotherspoon G (1991) 'City of the Plain': History of a Gay Sub-culture. Sydney: Hale and Iremonger.

Young A (1996) Imagining Crime: Textual Outlaws and Criminal Conversations. London: Sage. 